\title{
Is a 30\% Reduction in Emissions by Changing Transport Patterns in Ankara Feasible?
}

\author{
Can Biyık
}

\begin{abstract}
The purpose of this paper is to examine potential air pollution reductions by shifting people's transport pattern into public buses from passenger cars. A quantitative survey approach is used to estimate car driver's transport characteristics and some data are collected from local council website for public bus journeys. DMRB (Design Manual for Roads and Bridges) excel spread sheet is used to calculate local and regional air pollution emissions from passenger vehicles and public buses. In this research, I have found that there is a high potential of people prefer public buses in future but this potential does not provide to decrease all emissions of $30 \%$ of reductions because NOx emissions decrease less than other pollutants. Another important finding is that new local benzene and 1.3-butadieneair quality values could meet the national air pollution standards, if the $42 \%$ of car drivers are encouraged to travel by public buses in Ankara.
\end{abstract}

Index Terms-Air pollution, air quality, environment, transport.

\section{INTRODUCTION}

The transportation sector plays an important role in Turkey. The country is recently the sixth largest motor vehicle producers in Europe. Moreover, the number of automobiles in Turkey has been rapidly rising during the last decade. For example, car ownership rate has been surprisingly increased at 96 percent in the last decade [1]. It is also expected that middle-income countries, especially high rates of income growth OECD (Organization for Economic Co-operation and Development) countries, such as Portugal, Greece, and Turkey will have the most rapid increase in the car ownership for 2030 [2].

As the number of vehicles has increased, car-based cities are leading to poor sustainability cities [3]. The steady increase in motor vehicles will create a profound effect upon the environment because Turkish road transport system is responsible for $20 \%$ of all $\mathrm{CO}_{2}$ emissions and three quarters of the city's $\mathrm{CO}$ emissions each year. Therefore, road transportation is considerably responsible for the greenhouse effect which is related predominantly by $\mathrm{CO}_{2}$ emissions [4]

High levels of motor vehicles can also give rise to the greenhouse gas effect for transport experts and policy makers. For instance, Turkish Government has an important duty to decrease air pollution emissions from road transportation and needs considerable efforts for environment and climate change chapter (one of 35

Manuscript received January 18, 2014; revised April 24, 2014

Can Biyık is with School of Geography, Earth and Environmental Science, University of Birmingham, United Kingdom (e-mail: cxb110@adf.bham.ac.uk). chapters) in order to accede to the European Union. The Governments' strategies and policies are totally incompatible with legislation.

It seems that the literature reveals the potential for increasing mode share of public buses and associated climate policies has not been particularly reported within the context of $\mathrm{CO}_{2}$ reductions. Decreasing automobile trip with a corresponding increase in public transport trip lengths could have an important impact on both $\mathrm{CO}_{2}$ emissions and fuel consumption. Debate continues about transport and land use strategies to reduce $\mathrm{CO}_{2}$ emissions from road vehicles [5].

The rationale of this project is to raise public awareness and behaviour change in urban sustainable transport and Turkey could not wait for a well-developed sustainable transport with much higher dependence on public transport for the 2030 targets because the country's fast-growing transport sector and poor urban planning strategies still create huge environmental sustainability problems.

\section{Methodology}

\section{A. Selection of Study Areas}

The capital city of Turkey, Ankara is chosen as an example city for investigating the potential emission reductions by shifting car drivers' transport pattern to public buses. The first reason is that Ankara has the highest car ownership with $28 \%$ in Turkey. Secondly, the provision of additional road space becomes more problematic solution due to a lack of available space. This traditional approach of creating additional road capacity to decrease traffic congestion is not sufficient in Ankara. Finally, the topographic and weather feature of the city discourages people to use sustainable transport for long distances.

\section{B. DMRB Air Quality Model}

The DMRB excel spread sheet is a simple tool for evaluating road schemes (regional and local air quality local) and calculating pollutant concentrations at receptor locations. The input title of DMRB:

- Average distance travelled by a public bus or car (m)

- AADT (Number of vehicles on each road/day)

- The average speed of the bus or passenger car $(\mathrm{km} / \mathrm{h})$

- Road type (A, B, C, D)

- Split of the vehicle type (LDV, HDV)

- Distance from road

\section{Data Collection}

The input data is found from the local council website for public bus information. There are approximately 1220 public buses and the average distance, the total distance and 
the total shuttle time was taken for each public bus. Taking the total time information for each bus, the average speeds of the buses were calculated. Thus, it is possible to find the average input data for public bus after some mathematical calculations are done.

However, there is no fix route for each car drivers' journeys. Their journeys are undoubtedly too complex and different. Aquantitative survey is held over two weeks which includes 5 questions and 500 random representatives in order to predict the input values. A major difference is that passenger cars may not be driven every day. Therefore, the $2^{\text {nd }}$ question of the survey asks the survey participants to report the average days of using their passenger cars. Then, the number of registered passenger vehicles $(1,285,661)$ is multiplied by $4.95 / 7$ (as shown in Appendix I) for estimating the average active passenger vehicles in traffic. The $5^{\text {th }}$ question of the survey asks the car drivers to tell how they may be satisfied in terms of using public buses if public transport strategies are developed. The car driver participants are categorized into two groups: public bus users and passenger car users. So that $42 \%$ of car drivers also use public buses as well as passenger cars that help to decrease the number of vehicle usage and traffic congestion. (Appendix I)

TABLE I:The MAIn CHARACTERISTICS OF Public BuSES AND PASSENGER VEHICLE IN ANKARA

\begin{tabular}{|c|c|c|c|c|}
\hline $\begin{array}{c}\text { Main } \\
\text { Districts }\end{array}$ & $\begin{array}{c}\text { The } \\
\text { Average } \\
\text { Total } \\
\text { Road } \\
\text { length km }\end{array}$ & $\begin{array}{c}\text { The } \\
\text { Average } \\
\text { Traveling } \\
\text { Time min }\end{array}$ & $\begin{array}{c}\text { The } \\
\text { Average } \\
\text { Speed } \\
\mathrm{km} / \mathrm{hr}\end{array}$ & $\begin{array}{c}\text { The } \\
\text { Number } \\
\text { of Total } \\
\text { Shuttle }\end{array}$ \\
\hline $\begin{array}{c}\text { Public } \\
\text { Buses }\end{array}$ & 43.85 & 88.08 & 29.87 & 12,168 \\
\hline $\begin{array}{c}\text { Passenger } \\
\text { Vehicles }\end{array}$ & 27.34 & 32.98 & 49.74 & 909,145 \\
\hline
\end{tabular}

The Table I above illustrates some of the average travel characteristics of the public buses and passenger cars. These required features provide to estimate air pollution emissions from these main modes.

\section{Road Transport Pollutants}

The regional emissions calculate 5 pollutant emissions; carbon monoxide (CO), nitrogen oxides (NOx), total hydrocarbons (THC), and particulate matters $\left(\mathrm{PM}_{10}\right)$. The local emissions calculate pollutant concentrations for 6 pollutants; benzene, 1.3, butadiene, particulate matters, nitrogenoxides, and carbon monoxide. Local pollutant concentrations for a receptor which is located one metre from main roads. The minimum distance is modelled because pedestrians are usually very close to vehicle motor exhaust.

\section{RESUlts}

\section{A. The Calculations of Regional Emissions}

Table II estimates thecurrent total emission values obtained from the preliminary analysis of public transport and passenger car journeys. Table III shows the new total emsissions of public transport and passenger vehicles after $42 \%$ of car drivers use public buses instead of their own motor vehicles. Table III also provides the percentage reductionsinfour transport pollutants.
TABLE II: THE PRESENT REGIONAL EMISSIONS FROM ROAD TRANSPORT

\begin{tabular}{|c|c|c|c|c|}
\hline & $\begin{array}{c}\mathrm{CO} \\
\mathrm{kg} / \mathrm{yr}\end{array}$ & $\begin{array}{c}\mathrm{THC} \\
\mathrm{kg} / \mathrm{yr}\end{array}$ & $\begin{array}{c}\mathrm{NOx} \\
\mathrm{kg} / \mathrm{yr}\end{array}$ & $\begin{array}{c}\mathrm{PM}_{10} \\
\mathrm{~kg} / \mathrm{yr}\end{array}$ \\
\hline $\begin{array}{c}\text { Public } \\
\text { Transport }\end{array}$ & 259,059 & 106,166 & $1,147,519$ & 18,679 \\
\hline $\begin{array}{c}\text { Passenger } \\
\text { Vehicles }\end{array}$ & $8,744,603$ & 936,536 & $3,258,037$ & 117,362 \\
\hline $\begin{array}{c}\text { Total } \\
\text { Pollutants }\end{array}$ & $9,003,662$ & $1,042,702$ & $4,405,555$ & 136,041 \\
\hline
\end{tabular}

Comparing to Table II and Table III, there is a great decrease in carbon dioxide emissions by nearly $40 \%$. Total hydrocarbon and particulate matter reduce between $30 \%$ and $35 \%$. On the other hand, a decrease in NOx emissions is equivalent to $20 \%$, although NOx emissions decrease 886 tons per year.

TABLE III: THE NEW REGIONAL EMISSIONS FROM ROAD TRANSPORT

\begin{tabular}{|c|c|c|c|c|}
\hline & $\begin{array}{c}\mathrm{CO} \\
\mathrm{kg} / \mathrm{yr}\end{array}$ & $\begin{array}{c}\mathrm{THC} \\
\mathrm{kg} / \mathrm{yr}\end{array}$ & $\begin{array}{c}\mathrm{NOx} \\
\mathrm{kg} / \mathrm{yr}\end{array}$ & $\begin{array}{c}\mathrm{PM}_{10} \\
\mathrm{~kg} / \mathrm{yr}\end{array}$ \\
\hline $\begin{array}{c}\text { Public } \\
\text { Transport }\end{array}$ & 367,863 & 150,755 & $1,629,476$ & 26,524 \\
\hline $\begin{array}{c}\text { Passenger } \\
\text { Vehicles }\end{array}$ & $5,071,870$ & 543,190 & $1,889,661$ & 68,069 \\
\hline $\begin{array}{c}\text { Total } \\
\text { Pollutants }\end{array}$ & $5,439,733$ & 693,945 & $3,519,137$ & 94,593 \\
\hline Percentage & $39.58 \%$ & $33.45 \%$ & $20.12 \%$ & $30.47 \%$ \\
\hline
\end{tabular}

\section{B. The Calculations of Local Air Quality}

Comparing to Table IV and Table V, Benzene pollutants have the highest decrease by $42 \%$ in all example pollutants. 1.3-butadiene and carbon monoxide is reduced by $34.7 \%$ and $31.1 \%$, respectively. Local particulate matter emissions decrease about $7 \%$ from $10.38 \mu \mathrm{g} / \mathrm{m}^{3}$ to $9.67 \mu \mathrm{g} / \mathrm{m}^{3}$. These results also demonstrated that a $30 \%$ reduction in emissions by changing transport pattern is not feasible due to local $\mathrm{PM}_{10}$ and NOx concentrations. Moreover, local benzene emissions reduced from $5.63 \mu \mathrm{g} / \mathrm{m}^{3}$ to $3.27 \mu \mathrm{g} / \mathrm{m}^{3}$ and 1.3 butadiene emissions reduced from $3.03 \mu \mathrm{g} / \mathrm{m}^{3}$ to $1.98 \mu \mathrm{g}$ $/ \mathrm{m}^{3}$. One contribution of this study is that 1.3 - butadiene and benzene emissions could meet with national standards if $42 \%$ of car drivers leave their vehicle for public buses. The national standards are $5 \mu \mathrm{g} / \mathrm{m}^{3}$ for benzene and $2.25 \mu \mathrm{g} / \mathrm{m}^{3}$ for 1.3-butadiene.

TABLE IV: THE PRESENT LOCAL AIR QUALITY FROM ROAD TRANSPORT
\begin{tabular}{|c|c|c|c|c|c|}
\hline & $\begin{array}{c}\mathrm{CO} \\
\left(\mathrm{mg} / \mathrm{m}^{3}\right)\end{array}$ & $\begin{array}{c}\text { Benzene } \\
\left(\mu \mathrm{g} / \mathrm{m}^{3}\right)\end{array}$ & $\begin{array}{c}1,3- \\
\text { butadiene } \\
\left(\mu \mathrm{g} / \mathrm{m}^{3}\right)\end{array}$ & $\begin{array}{c}\mathrm{NOx} \\
\left(\mu \mathrm{g} / \mathrm{m}^{3}\right)\end{array}$ & $\begin{array}{c}\mathrm{PM}_{10} \\
\left(\mu \mathrm{g} / \mathrm{m}^{3}\right)\end{array}$ \\
\hline $\begin{array}{c}\text { Public } \\
\text { Transport }\end{array}$ & 0.05 & 0.01 & 0.27 & 88.39 & 4.34 \\
\hline $\begin{array}{c}\text { Passenger } \\
\text { Vehicles }\end{array}$ & 0.41 & 5.62 & 2.76 & 41.00 & 6.04 \\
\hline $\begin{array}{c}\text { Total } \\
\text { Pollutants }\end{array}$ & 0.45 & 5.63 & 3.03 & 129.39 & 10.38 \\
\hline
\end{tabular}

TABLE V: THE NEW LOCAL AIR QUALITY FROM ROAD TRANSPORT

\begin{tabular}{|c|c|c|c|c|c|}
\hline & $\begin{array}{c}\mathrm{CO} \\
\left(\mathrm{mg} / \mathrm{m}^{3}\right)\end{array}$ & $\begin{array}{c}\text { Benzene } \\
\left(\mu \mathrm{g} / \mathrm{m}^{3}\right)\end{array}$ & $\begin{array}{c}1,3- \\
\text { butadiene } \\
\left(\mu \mathrm{g} / \mathrm{m}^{3}\right)\end{array}$ & $\begin{array}{c}\mathrm{NOx} \\
\left(\mu \mathrm{g} / \mathrm{m}^{3}\right)\end{array}$ & $\begin{array}{c}\mathrm{PM}_{10} \\
\left(\mu \mathrm{g} / \mathrm{m}^{3}\right)\end{array}$ \\
\hline $\begin{array}{c}\text { Public } \\
\text { Transport }\end{array}$ & 0.05 & 0.01 & 0.27 & 88.39 & 4.34 \\
\hline $\begin{array}{c}\text { Passenger } \\
\text { Vehicles }\end{array}$ & 0.41 & 5.62 & 2.76 & 41.00 & 6.04 \\
\hline $\begin{array}{c}\text { Total } \\
\text { Pollutants }\end{array}$ & 0.31 & 3.27 & 1.98 & 149.29 & 9.67 \\
\hline Percentage & $31.1 \%$ & $41.9 \%$ & $34.7 \%$ & $-15.4 \%$ & $6.8 \%$ \\
\hline
\end{tabular}




\section{DisCUSSION}

This study set out with the aim of assessing the importance of using public buses instead of passenger cars. This study also confirms that encouraging people to use public transport mode is highly associated with decreasing air pollution emissions in urban cities. One unanticipated finding was that the survey results of this research indicate that there is huge potential of people could use public buses but they currently use their passenger vehicles as a consequence of a lack of public transport policy development. Therefore, unsustainable transportation system makes a negative impact to the environmental structure of the urban cities. The negative influences of public buses and other public transport modes may become more concern topic to the urban communities, transport experts, and national policy makers.

The study discussions are consistent with those of other transport and environment studies and suggest that improving public transport mode shares would realize the Turkey's environment and climate change policy and air quality objectives. Moreover, walking and cycling are also the most common transport mode of achieving environmental objectives.

It is also recommended that the sustainable transportation planning must have an in-depth understanding of travel habits and demands and current transport problems before developing urban transport policies. Furthermore, a more combined approach of transport policy should be integrated with land-use planning policies in order to decrease the number of passenger vehicles and improve Turkish sustainable transport system. Smart growth form more accessible land use designs and to decrease the demand of travel needed. So that smart growth could be good trend that specified this integration for the future of Turkey.

Finally, this research finding is that $\mathrm{PM}_{10}$ and $\mathrm{NOx}$ emission are the most critical pollutants in Ankara. This study found that NOx is still much higher than Turkish National Standards $\left(149.29 \mu \mathrm{g} / \mathrm{m}^{3}>30 \mu \mathrm{g} / \mathrm{m}^{3}\right)$, although $42 \%$ car drivers start to use public transport instead of passenger vehicles. The reason for this is not clear but it may be associated with diesel engine motor cars because diesel engine car produces much more $\mathrm{PM}_{10}$ and $\mathrm{NOx}$ emissions than petrol engine car. Therefore, local and national policy makers and transport experts may work with other stakeholders to reduce emissions from diesel engine motor vehicles. Another important finding may corroborates the idea of NOx emission increase is associated with early inefficient regulations in the transport sector [6].

\section{Limitations}

The main limitation is that it was not possible to calculate meteorological data and $\mathrm{PM}_{2.5}$ concentrations. Secondly, road transport emissions are automatically calculated based on UK emission factors for Turkish case study but the medium age of Turkish car vehicles is approximately 5 years older than UK cars. Thus, the road transport emissions could be calculated by more comprehensive method but it would be more difficult to find required data. Another major source of uncertainty is to investigate the significant relationships of calculating $\mathrm{NO}_{2}$ concentrations from NOx. Final limitation is that taxis are also third biggest travel mode in Ankara, and they are not considered in this study.

\section{CONCLUSION}

The results of this method show that $\mathrm{CO}$, THC, and $\mathrm{PM}_{10}$ decrease more than 30 percent, and however, the amount of NOx emissions is expected to decrease at 20 percent. Therefore, a $30 \%$ reduction in emissions by changing transport patterns in Ankara is not feasible. However, this paper has still argued that encouraging car drivers to use public transport is a useful method to reduce air pollution emissions from passenger vehicles. One of the more significant findings to emerge from this study is that benzene and 1, 3-butadiene concentrations below the national standards after 42 percent of car drivers start to use public buses. Other social finding is that there is high public potential tend to use public transport as a main transport mode.

Thus, an integrated package of policy measures could be helpful to optimize and improve public transport model in order to change the current city to a sustainable city. Therefore, local municipalities, transport experts, and policy makers could develop public transport policy within the context of reducing $\mathrm{PM}_{10}$ and NOx emissions.

It is recommended that further research be undertaken in the following areas:

- Why $\mathrm{PM}_{10}$ and NOx emissions are more problematic pollutants? How these pollutants can be mitigated?

- How an integrated package of transport policies is helpful to reduce NOx emissions?

- What public transport strategies are effective to decrease $\mathrm{CO}_{2}$ emissions from road transport vehicles in Turkey?

\section{APPENDIX}

The results of survey for drivers are shown in Table VI.

TABLE VI: THE RESULTS OF SURVEY FOR DRIVERS

\begin{tabular}{|c|c|c|c|c|c|c|}
\hline & & & & & & \\
\hline$Q 1$ & $0-10$ & $\begin{array}{c}10- \\
20\end{array}$ & $\begin{array}{c}20- \\
30\end{array}$ & $\begin{array}{c}30- \\
40\end{array}$ & $\begin{array}{c}40- \\
50\end{array}$ & $\begin{array}{c}\text { Average } \\
\text { Roads }(\text { Km })\end{array}$ \\
\hline & $\mathbf{4 9}$ & $\mathbf{9 2}$ & $\mathbf{1 4 4}$ & $\mathbf{1 2 3}$ & $\mathbf{9 2}$ & $\mathbf{2 7 . 3 4} \mathbf{~ k m}$ \\
\hline$Q 2$ & 3 & 4 & 5 & 6 & 7 & Average Days \\
\hline & $\mathbf{4 3}$ & $\mathbf{8 4}$ & $\mathbf{2 7 5}$ & $\mathbf{4 9}$ & $\mathbf{4 9}$ & $\mathbf{4 . 9 5}$ days \\
\hline$Q 3$ & 1 & 2 & 3 & 4 & 5 & Average People \\
\hline & $\mathbf{3 9 1}$ & $\mathbf{5 7}$ & $\mathbf{2 9}$ & $\mathbf{1 7}$ & $\mathbf{6}$ & $\mathbf{1 . 3 8}$ people \\
\hline$Q 4$ & $0-15$ & $\begin{array}{c}15- \\
30\end{array}$ & $\begin{array}{c}30- \\
45\end{array}$ & $\begin{array}{c}45- \\
60\end{array}$ & $\begin{array}{c}60- \\
75\end{array}$ & $\begin{array}{c}\text { Average Time } \\
\text { (min) }\end{array}$ \\
\hline & $\mathbf{9 0}$ & $\mathbf{1 3 9}$ & $\mathbf{1 4 1}$ & $\mathbf{9 3}$ & $\mathbf{3 7}$ & $\mathbf{3 2 . 9 8} \mathbf{m i n}$ \\
\hline$Q 5$ & $0-20$ & $20-$ & $40-$ & $60-$ & $80-$ & $\begin{array}{c}\text { Satisfaction in } \\
\text { Public Bus } \%\end{array}$ \\
\hline & $\mathbf{7 5}$ & $\mathbf{1 6 2}$ & $\mathbf{1 6 7}$ & $\mathbf{7 0}$ & $\mathbf{2 6}$ & $\mathbf{4 2 . 4} \%$ \\
\hline
\end{tabular}

\section{REFERENCES}

[1] S. Soylu, "Estimation of Turkish road transport emissions," Energy Policy, vol. 35, pp. 4088-4094, 2007.

[2] J. Dargay, D. Gately, and M. Sommer, "Vehicle ownership and income growth, worldwide: 1960-2030," The Energy Journal, vol. 28 , no. 4, pp. 143-170, 2007

[3] K. Stanley, A. Hensder, and C. Loader, "Road transport and climate change: Stepping off the greenhouse gas," Transportation Research Part A: Policy and Practice, vol. 45, pp. 1020-1030, 2011. 
[4] C. De Jong and O. Van De Riet, "The driving factors of passenger transport," European Journal of Transport and Infrastructure Research, vol. 8, no. 3, pp. 227-250, 2007.

[5] J. Woodcock, P. Edwards, C. Tonne, B. Armstrong, O. Ashiru, D. Banister, S. Beevers, Z. Chalabi, Z. Chowdhury, and A. Cohen, "Public health benefits of strategies to reduce greenhouse-gas emissions: urban land transport," The Lancet, vol. 374, no. 9705, pp. 1930-1943, 2009.

[6] V. Vestreng, L. Ntziachristos, A. Semb, S. Reis, I. Isaksen, and L. Tarrason, "Evolution of NO x emissions in Europe with focus on road transport control measures," Atmospheric Chemistry and Physics, vol. 9, pp. 1503-1520, 2009.

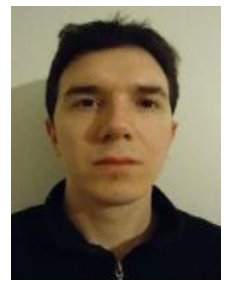

Can Blyık obtained his first degree at Anadolu University, Turkey with an Honours degree in environmental engineering in 2010. He then moved to School of Geography, Earth and Environmental Science in the University of Birmingham to do a master degree, completing in 2012. His doctorate studies started at University of Birmingham in the Civil Engineering where his thesis is to create environmentally sustainable transport systems for the future of Turkish urban cities. 